\title{
IDENTIFICATION OF FOREST COVER VARIATION IN MANNAR DISTRICT, SRI LANKA USING GIS AND REMOTE SENSING TECHNIQUES
}

\author{
Luxmini K. P. A. M. K, Kishoran S, Sivanantharajah S, Gunatilake J \\ Postgraduate Institute of Science, University of Peradeniya, \\ Peradeniya, Sri Lanka
}

\begin{abstract}
Geographic Information System (GIS) and Remote sensing acting a vital part in identifying changes in the forest cover. One of the most prominent feature is forest in Mannar district. It is crucial to estimate forest cover change on spatial and temporal scale for a sustainable forest resource management. And there were no any well studies taken to find out areal extent of forest cover change. The main objective of this study was to estimate the magnitude of forest cover change for the years 1997, 2008 and 2015. Also identify its spatial distribution and analyse the spatio temporal changes of the forest. Further forest cover maps were produced of the study area for the respective years. Research study was used the supervised, unsupervised and NDVI classification to evaluate the total forest cover. The results revealed high kappa accuracy in percentage of forest cover for the years 1997, 2008 and 2015 were $82 \%, 74 \%$ and $81 \%$ and overall accuracies were $86 \%, 81 \%$ and $87 \%$ respectively for the supervised classification. According to the supervised classification study indicates the forest cover extent of 1997,2008 and 2015 were $1,254 \mathrm{~km}^{2}$ $(63 \%), 1,299 \mathrm{~km}^{2}(65 \%)$ and $1,161 \mathrm{~km}^{2}(59 \%)$. It revealed that, $2 \%$ of forest cover was increased from 1997 to 2008 and $6 \%$ was reduced from 2008 to 2015. The study indicated that forest cover change is an immense problematic issue in the district, where about $119 \mathrm{~km}^{2}(6 \%)$ of forest cover decreased in 2015. The main factors of forest cover reduction in the district might be anthropogenic activities.
\end{abstract}

Keywords - Forest cover, GIS, Remote sensing, supervised classification.

\section{INTRODUCTION}

Asia is one of the regions of the world forest with the highest number of vulnerable species. In 1990s 0.6 million hectares net loss per year. Average net gain was more than 2.2 million hectares per year in 2000 to 2010. South and Southeast Asia deforestation was continued and 2.4 million hectares net loss was reported in 1990s per year [1].

Throughout Asia, the expansion and intensification of agricultural activities were the principal reasons for ongoing deforestation [2]. Underlying causes of land use and land cover (LULC) change leading to deforestation and land degradation include rapid economic development, population growth, and poverty [3]. The main driving forces of spatial transformations were related to different natural, demographic such as population growth, settlement expansion and political factors such as political decisions influenced the property status, type of exploitation, etc. which were directly responsible for land use change patterns [4], thus triggering forest cover transformation.

Forest cover in Sri Lanka had decreased rapidly during last century and only fragments of the once widespread natural forest cover remain. Main factors of deforestation were settlements, according to the Jagath Ratnayake et al. [5]. There were four main districts namely Mannar, Puttalam, Trincomalee and Vavuniya having a serious forest cover reduction in the period of 1992-2001. Due to weak enforcement of rules and regulations dense forest had been affected by encroachments which was the main reason for this [6].

According to the forest department of Sri Lanka, reported that about 2,500 hectares of forest land had 
been encroached in forest reserves in 1991 to 1996 [7]. Forest cover changes could documented locally through field based studies, however, at regional to global scales it required an approach based on remote sensing. Satellite data had become a major application in forest change detection because of the repetitive coverage of the satellite at short interval [8].

Forest is one of the most prominent features of Mannar District, which consist dry monsoon forests, riverine dry forests, dense forests and mangrove forest. Resettlements, agriculture expansion, urbanizations, illegal logging and other developments leads to forest cover change in the district. Therefore, it is necessary to estimate forest cover change on spatial and temporal scales. The main objective of this study was to estimate the magnitude of forest cover change for the years 1997, 2008 and 2015 of mannar district. Also identified its spatial distribution and analyse the spatio temporal changes of the forest.

\section{MATERIAL AND METHODS}

\section{A. Study area-}

The area selected for the study was Mannar district which was located in the North West of Sri Lanka in the Northern Province, covering a land area of 2,002 $\mathrm{km}^{2}$ and was shown in Figure 1. It lays in between geographical coordinates longitudes $79^{\circ} 55^{\prime} \mathrm{E}$ and latitudes $08^{0} 59^{\prime} \mathrm{N}$. Forest is one of the most important features of the district [9].

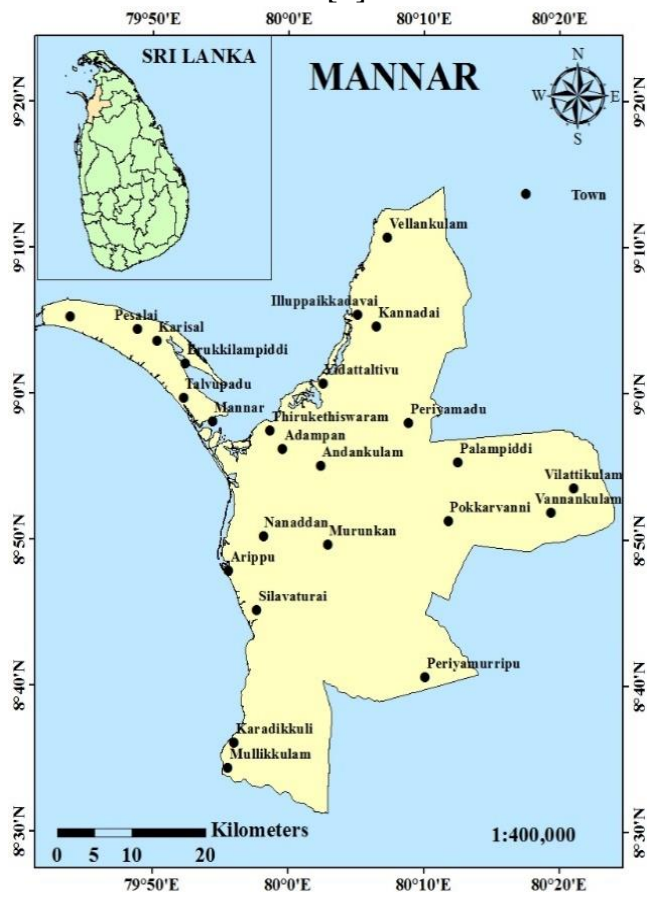

Fig. 1. Study area map

\section{B. Software-}

In this study ArcGIS 10.3, ERDAS IMAGINE 2014 and Microsoft Excel were used. All classifications and process were performed using ArcGIS 10.3. ERDAS IMAGINE 2014 was chosen for haze removal. Accuracy assessment was applied through Microsoft Excel. Although they were partially generated within ArcGIS, they needed to be refined with the aid of Microsoft Excel.

\section{Landsat Data Selection-}

Landsat data were selected for three particular years 1997, 2008 and 2015. United State Geological Survey website was used to download the satellite images for the study area. Cloud cover which was less than $10 \%$ of images were selected. Landsat 5 and Landsat 8 images were downloaded for 1997, 2008 and 2015 years. The whole study area was covered by two paths of satellite images (Path-141, Row-54 and Path-142, Row-54). For the year 1997 and 2008, Landsat 5 images and for years 2015 Landsat 8 images were used.

\section{Digital Image Processing-}

ERDAS IMAGINE software was used to perform haze removal. Composite tool was used to convert the six layers for Landsat 5 and 7 layers for Landsat 8 satellite images into a single layer file. Two different paths images were mosaicked for the respective years. Then output images were projected to WGS 1984 UTM zone $44 \mathrm{~N}$. The masking method was used to resize the images into desired size of the study area [10] where each image was prepared for analysis.

\section{E. Ground Control Points-}

Ground Control Points (GCP) are created on the basis of field work which was difficult due to time consumption, cost and difficult to getting certain places. Since, Google Earth map was used to develop ground control points. GCP were used for accuracy assessment.

\section{F. Normalized Difference Vegetation Index (NDVI)-}

The NDVI was calculated based on the following equation,

$\mathrm{NDVI}=(\mathrm{NIR}-\mathrm{RED}) /(\mathrm{NIR}+\mathrm{RED})$ 
Where, NIR denotes to the near-infrared wavelength and red denotes the wavelength in the red band [11]. In this study area four land use classes such as forest, water, agriculture and barren and built up area were identified and model builder was created to perform process for NDVI of each year separately.

\section{G. Image Classification-}

In this study unsupervised classification and supervised classification were selected to find out forest cover change for the years 1997, 2008 and 2015. ISO clustering is unsupervised classification there is minimum requirement for user's intervention. Input raster study area image and number of classes four were selected and into which cells were grouped. After these parameters were set, the tool performed the classification and the classified output raster was retrieved [12].

Maximum likelihood is the common method of supervised classification, which was applied for study images [13]. Google Earth was used to develop signatures as ground control points and used for the accuracy of classification. Training sites were created for each year separately using standard procedure through ArcGIS 10.3 image classification tool by drawing them over the areas of each of distinguished land cover. Approximately 15 signature samples were selected for four particular classes that are forest, water, agriculture and barren and built up area. Supervised classification process was carried for each year separately by creating model builder.

\section{H. Accuracy Assessment-}

Confusion Matrices were used to assess classification accuracy of remotely sensed data. Outputs of the three tested classification methods for each year were compared against ground truth data. In this study, confusion matrix was carried by 40 ground truth points features for each class altogether 160 points were randomly selected. For the locations where the values were compared, Training sample file which was created for sampling and containing point features were used as the input. Frequency table was used for summaries how many predictions were made for every ground truth class. The pivot table was used to transform the information into a Confusion Matrix arrangement which re-organized the results. In order to finalize the tables, they were transported into Microsoft Excel. The overall accuracy, kappa coefficient, omission error (producer's accuracy), and commission error (user's accuracy) were computed for the years 1997, 2008 and 2015.

\section{RESULTS AND DISCUSSION}

\section{A. Forest cover and its spatial distribution-}

The study area was distinguished into four land cover classes; forest, water, barren and built up area and agriculture by use of supervised, unsupervised and NDVI technique for the years 1997, 2008 and 2015.

\section{Forest cover distribution in 1997-}

As presented in table 1, the satellite image of Mannar district for 1997 year yielded land cover map with the forest occupying the largest area coverage for supervised, unsupervised classification and NDVI were $1,254 \mathrm{~km}^{2}(63 \%), 1,241 \mathrm{~km}^{2}(62 \%)$ and 1,350 $\mathrm{km}^{2}(68 \%)$ as compared to other land cover classes. Land cover status was given in the Table 1 and map showing land cover for supervised, unsupervised and NDVI for 1997 in the Figure 2. Forest area (62\%) extent was less, water (4\%) and agriculture areas (27\%) were higher in unsupervised classification compared to the supervised classification. Forest area was higher extent in NDVI compared to the supervised and unsupervised classification in 1997. 


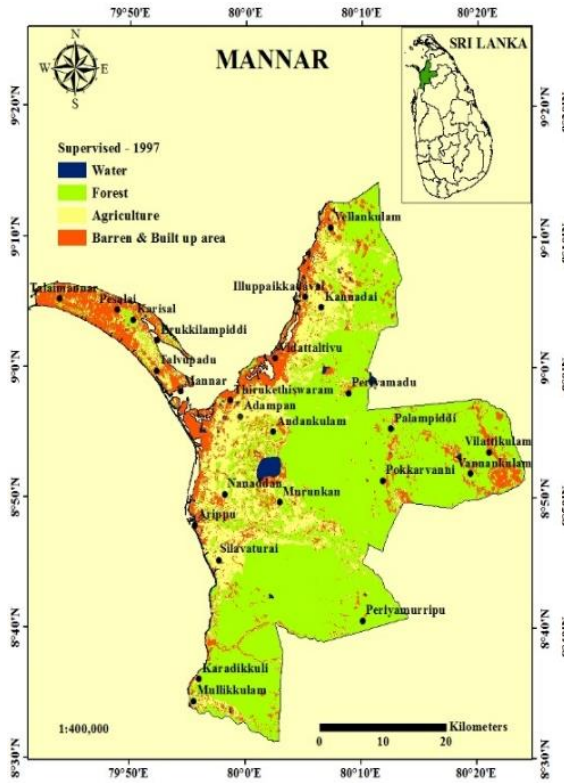

(A)

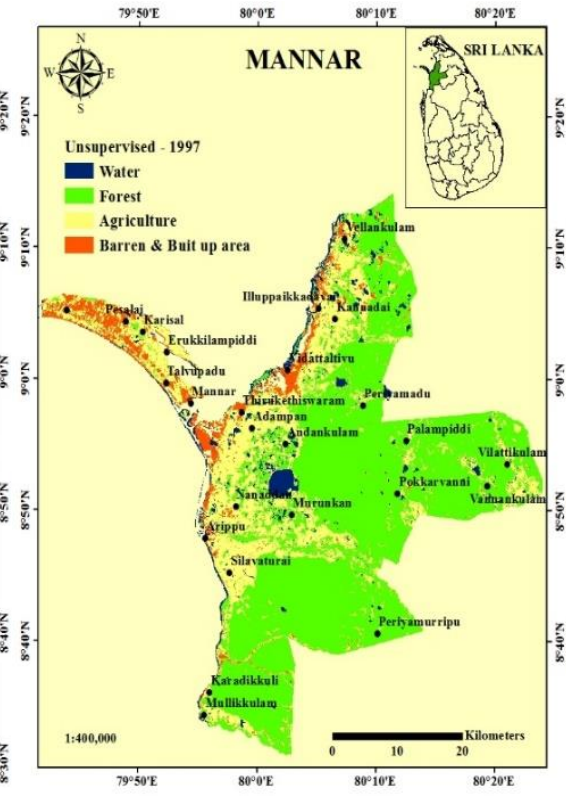

(B)

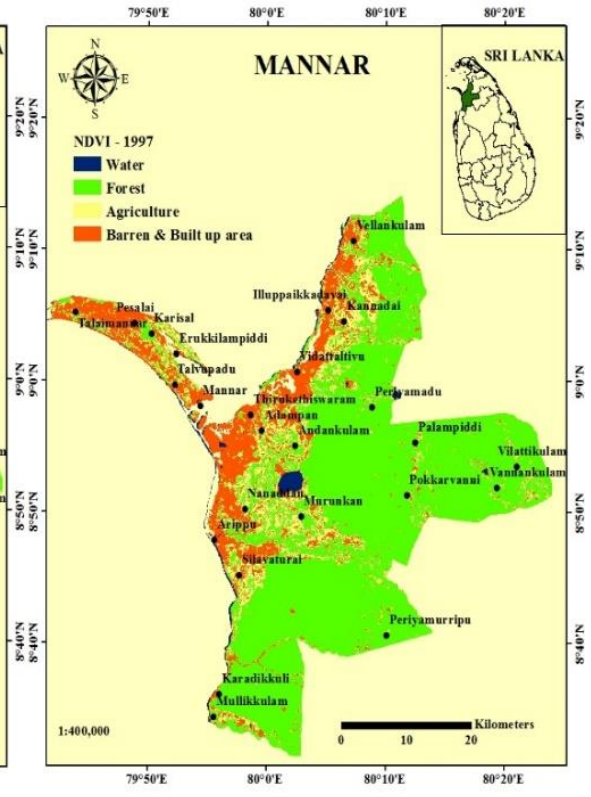

(C)

Fig. 2. Satellite map of Mannar district showing land cover (A - Supervised classification - 1997;

B- Unsupervised classification -1997; C- Normalized Difference Vegetation Index (NDVI) - 1997

Table 1 - Land cover distribution in 1997

\begin{tabular}{|l|c|c|c|c|c|c|}
\hline \multirow{2}{*}{$\begin{array}{l}\text { Land cover } \\
\text { class }\end{array}$} & \multicolumn{5}{|c|}{ Area and percentages of different technique in 1997} \\
\cline { 2 - 7 } & \multicolumn{2}{|c|}{ Supervised } & \multicolumn{2}{c|}{ Unsupervised } & \multicolumn{2}{c|}{ NDVI } \\
\cline { 2 - 7 } & Area $\left(\mathrm{km}^{2}\right)$ & Percentage (\%) & Area $\left(\mathrm{km}^{2}\right)$ & Percentage (\%) & Area $\left(\mathrm{km}^{2}\right)$ & Percentage (\%) \\
\hline Water & 39 & 2 & 88 & 4 & 31 & 2 \\
\hline Forest & 1,254 & 63 & 1,241 & 62 & 340 & 68 \\
\hline $\begin{array}{l}\text { Barren \& Built } \\
\text { up area }\end{array}$ & 330 & 17 & 115 & 6 & 26 & 17 \\
\hline Agriculture & 362 & 18 & 540 & 27 & 260 & 13 \\
\hline
\end{tabular}

\section{Forest cover distribution in 2008-}

The supervised, unsupervised and NDVI procedures applied to 2008 year satellite image yielded land cover map with the forest occupying the largest area coverage of $1,299 \mathrm{~km}^{2}(65 \%), 1,434 \mathrm{~km}^{2}(72 \%)$ and $1,520 \mathrm{~km}^{2}(77 \%)$ as compared to other land use classes. Land cover status of 2008 was given in the Table 2. Land cover map displayed in Figure 3 illustrated the water consist the area coverage of $1 \%$, forest $65 \%$, barren and built up area $18 \%$ and agriculture $15 \%$ in supervised classification for the year 2008. Barren land area extent was higher in year
$2008(18 \%)$ compared to 1997 (17\%) of supervised Classification whereas Forest cover was incresed by $2 \%$ in 2008 compared to year $1997(63 \%)$. In unsupervised classification of the year 2008, $17 \%$ of area was covered with the water, forest $72 \%$, barren and built up area $9 \%$ and agriculture $1 \%$. Water area was comparatively higher in unsupervised classification to the supervised classification. Acquisition date of 2008 satellites images were belonged to rainy season that were October and December month therefore most of the areas were in 


\section{International Journal of Engineering Applied Sciences and Technology, 2020 \\ Vol. 5, Issue 2, ISSN No. 2455-2143, Pages 69-77 \\ Published Online June 2020 in IJEAST (http://www.ijeast.com)}

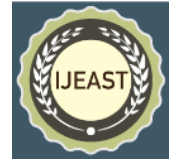

flooded conditions. Since in unsupervised classification most of the areas were classified as

by $12 \%$ and unsupervised classification by $5 \%$ in water area. The area of forest cover was $1,434 \mathrm{~km}^{2}$ 2008.

(72\%) which was higher extent compared to the supervised classification $1,299 \mathrm{~km}^{2}(65 \%)$. Forest area was higher extent in NDVI compared to the supervised

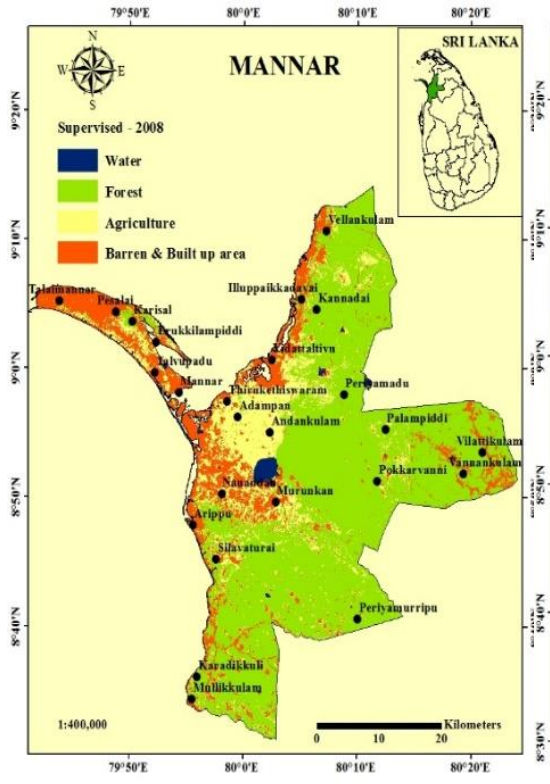

(A)

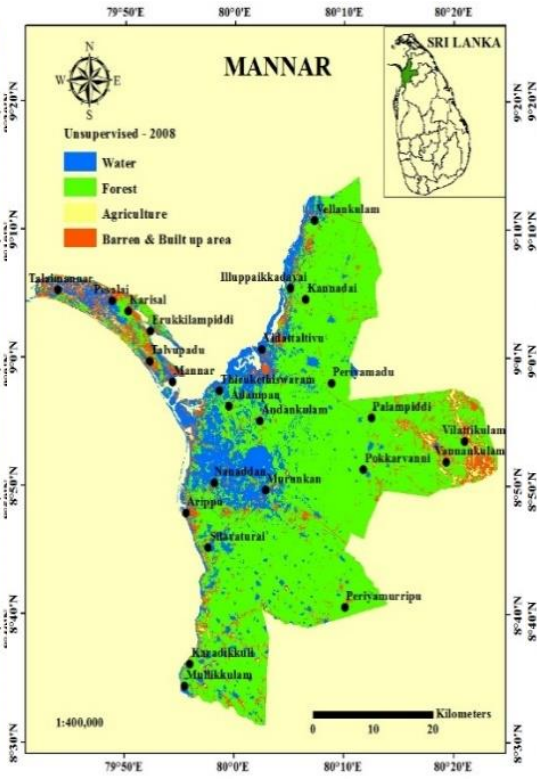

(B)

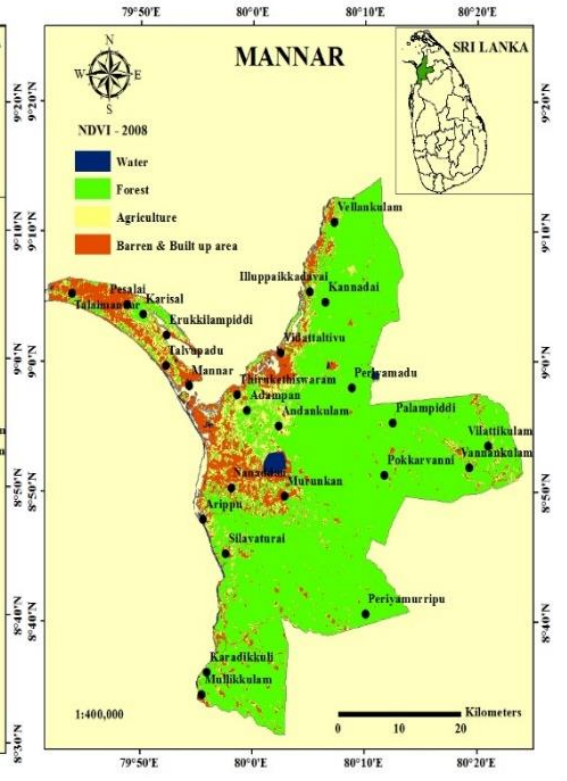

(C)

Fig. 3. Satellite map of Mannar district showing land cover (A - Supervised classification - 2008; B- Unsupervised classification -2008; C- Normalized Difference Vegetation Index (NDVI) - 2008

Table 2 - Land cover distribution in 2008

\begin{tabular}{|l|c|c|c|c|c|c|}
\hline \multirow{2}{*}{$\begin{array}{l}\text { Land cover } \\
\text { class }\end{array}$} & \multicolumn{5}{|c|}{ Area and percentages of different technique in 2008 } \\
\cline { 2 - 7 } & \multicolumn{2}{|c|}{ Supervised } & \multicolumn{2}{c|}{ Unsupervised } & \multicolumn{3}{c|}{ NDVI } \\
\cline { 2 - 7 } & Area $\left(\mathrm{km}^{2}\right)$ & Percentage (\%) & Area $\left(\mathrm{km}^{2}\right)$ & Percentage (\%) & Area $\left(\mathrm{km}^{2}\right)$ & Percentage (\%) \\
\hline Water & 29 & 1 & 344 & 17 & 30 & 2 \\
\hline Forest & 1,299 & 65 & 1,434 & 72 & 1,520 & 77 \\
\hline $\begin{array}{l}\text { Barren \& Built } \\
\text { up area }\end{array}$ & 354 & 18 & 178 & 9 & 257 & 13 \\
\hline Agriculture & 301 & 15 & 28 & 1 & & 9 \\
\hline
\end{tabular}

\section{Forest cover distribution in 2015-}

2015 year satellite image produced land cover map with the forest occupying the area coverage for supervised, unsupervised classification and NDVI were $1,161 \mathrm{~km}^{2}(59 \%), 1,294 \mathrm{~km}^{2}(65 \%)$ and 1,490 $\mathrm{km}^{2}(75 \%)$ as compared to other land use classes. Land cover status showed in the Table 3. Figure 4 displayed land cover of supervised, unsupervised classification and NDVI for the year 2015 where water comprises the area coverage of $1 \%$, forest $59 \%$, barren and built up area $15 \%$ and agriculture $25 \%$ in Supervised method. The area of forest cover was $1,161 \mathrm{~km}^{2}(59 \%)$ which was decreased in year 2015 compared to the year $2008\left(1,299 \mathrm{~km}^{2}\right)$. The area of forest cover was $1,490 \mathrm{~km}^{2}$ in NDVI which was higher in area compared to the supervised and unsupervised methods of classification. 


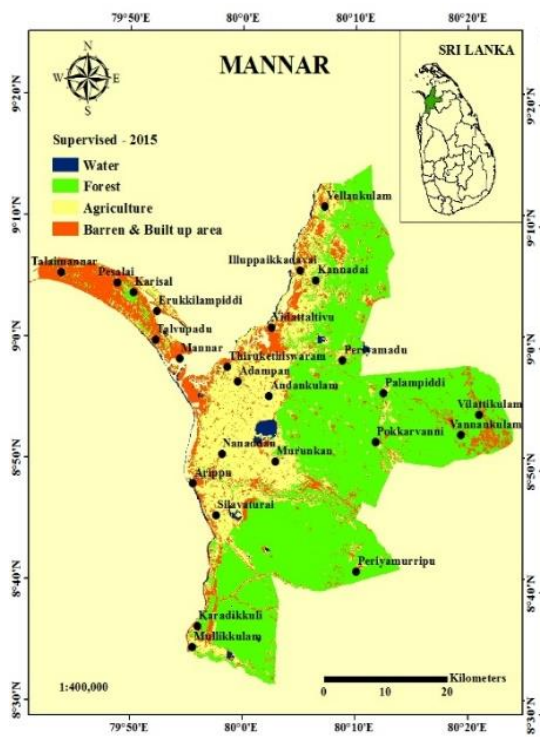

A

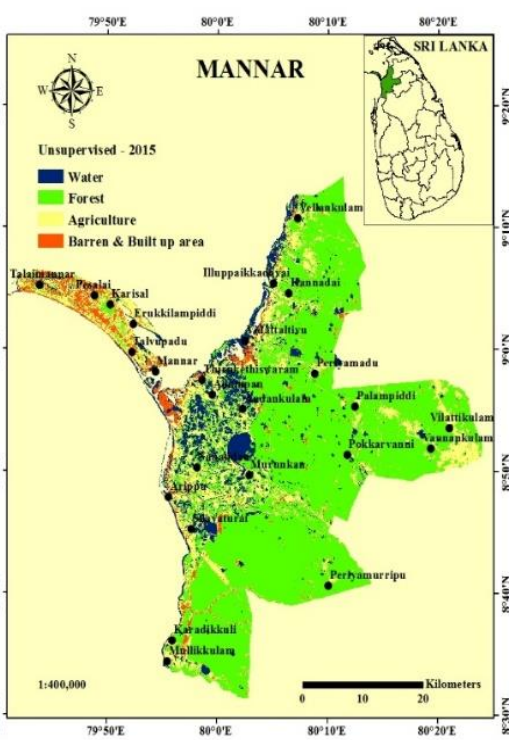

B

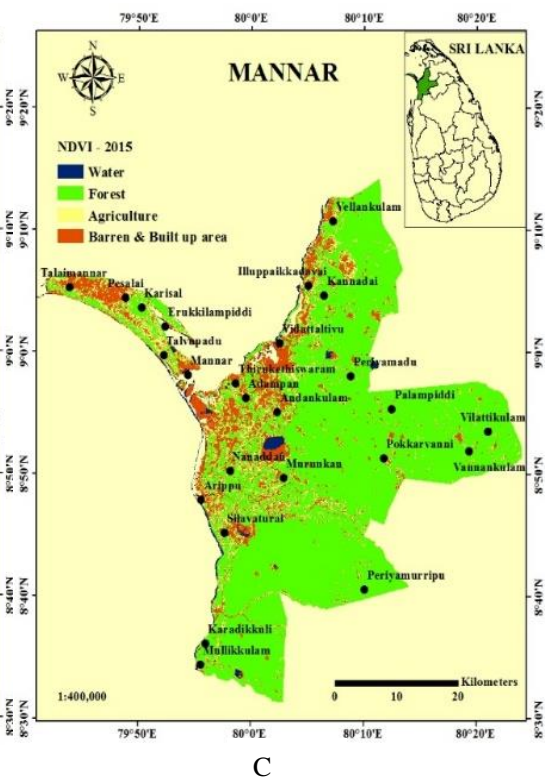

$\mathrm{C}$

Fig. 4. Satellite map of Mannar district showing land cover (A - Supervised classification - 2015; B- Unsupervised classification -2015; C- Normalized Difference Vegetation Index (NDVI) - 2015

Table 3 - Land cover distribution in 2015

\begin{tabular}{|l|c|c|c|c|c|c|}
\hline \multirow{2}{*}{$\begin{array}{l}\text { Land cover } \\
\text { class }\end{array}$} & \multicolumn{5}{|c|}{ Area and percentages of different technique in 2015 } \\
\cline { 2 - 7 } & \multicolumn{2}{|c|}{ Supervised } & \multicolumn{2}{c|}{ Unsupervised } & \multicolumn{2}{c|}{ NDVI } \\
\cline { 2 - 7 } & Area $\left(\mathrm{km}^{2}\right)$ & Percentage (\%) & Area $\left(\mathrm{km}^{2}\right)$ & Percentage (\%) & Area $\left(\mathrm{km}^{2}\right)$ & Percentage (\%) \\
\hline Water & 29 & 1 & 205 & 10 & 33 & 2 \\
\hline Forest & 1,161 & 59 & 1,294 & 65 & 264 & 75 \\
\hline $\begin{array}{l}\text { Barren \& } \\
\text { Built up area }\end{array}$ & 303 & 15 & 95 & 5 & & 13 \\
\hline Agriculture & 490 & 25 & 390 & 20 & 197 & 10 \\
\hline
\end{tabular}

B. Accuracy assessment-

Table 4 - Accuracy assessment for the years 1997, 2008 and 2015 of forest cover

\begin{tabular}{|l|c|c|c|}
\hline \multirow{2}{*}{} & \multicolumn{2}{|c|}{1997} & NDVI \\
\cline { 2 - 4 } & Supervised & Unsupervised & 71 \\
\hline Overall accuracy (\%) & 86 & 81 & 61 \\
\hline Kappa statistics (\%) & 82 & 75 & 71 \\
\hline User accuracy (\%) & 93 & 80 & 98 \\
\hline Producer accuracy (\%) & 95 & 93 & \\
\hline
\end{tabular}

\begin{tabular}{|l|c|c|c|}
\hline \multirow{2}{*}{} & \multicolumn{3}{|c|}{2008} \\
\cline { 2 - 4 } & Supervised & Unsupervised & NDVI \\
\hline Overall accuracy (\%) & 81 & 56 & 66 \\
\hline Kappa statistics (\%) & 74 & 42 & 54 \\
\hline
\end{tabular}


International Journal of Engineering Applied Sciences and Technology, 2020

Vol. 5, Issue 2, ISSN No. 2455-2143, Pages 69-77

Published Online June 2020 in IJEAST (http://www.ijeast.com)

\begin{tabular}{|l|l|l|l|}
\hline User accuracy $(\%)$ & 77 & 57 & 58 \\
\hline Producer accuracy $(\%)$ & 83 & 83 & 88 \\
\hline
\end{tabular}

\begin{tabular}{|l|c|c|c|}
\hline \multirow{2}{*}{} & \multicolumn{2}{|c|}{2015} & NDVI \\
\cline { 2 - 4 } & Supervised & Unsupervised & 69 \\
\hline Overall accuracy (\%) & 87 & 64 & 59 \\
\hline Kappa statistics (\%) & 81 & 53 & 56 \\
\hline User accuracy (\%) & 92 & 67 & 100 \\
\hline Producer accuracy (\%) & 90 & 80 & \\
\hline
\end{tabular}

The study indicated that increase number of kappa statistics, and overall accuracy were achieved by supervised classification compared to the unsupervised classification and NDVI of the years 1997, 2008 and 2015. The results revealed the forest cover class with high kappa accuracies in percentage for the years 1997, 2008 and 2015 were $82 \%, 74 \%$ and $81 \%$ and overall accuracies were $86 \%, 81 \%$ and $87 \%$ respectively for the supervised classification. Table 4 revealed overall accuracy, kappa statistics, and user and producer accuracy of forest cover class for the years 1997, 2008 and 2015. NDVI is the commonly used indicator for vegetation index, but accuracy assessment was low compared to other two methods because agriculture areas were classified as forest area in NDVI method.

\section{Forest cover change detection-}

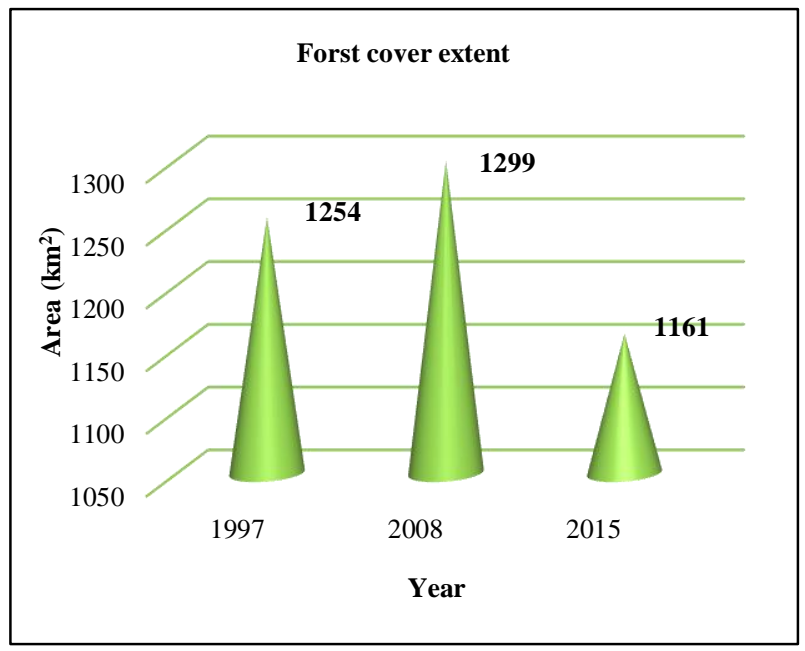

Fig. 5. Forest cover change in 1997, 2008 and 2015 for supervised classification

Supervised method was selected to estimate the final result of forest cover for the particular years since having higher overall accuracy. Figure 5 showed forest cover change extent in 1997, 2008 and 2015 of supervised classification. Forest cover increased $2 \%$ from 1997 to 2008 and which was reduced 6\% (approximately $119 \mathrm{~km}^{2}$ ) from 2008 to 2015 . After civil war there were lots of resettlement and development took place, and some drought condition also might be the reason for that reduction from year 2008 to 2015. It was indicated that some anthropogenic activities cause forest cover reduction from 2008 to 2015. The main factors of reduction of forest cover was human activities, such as resettlement, fire wood, illegal logging, chena cultivation, urbanization, road construction, and overgrazing. Climate change, such as extended drought might also exaggerate the deforestation [14].

\section{Comparison of forest cover by supervised classification-}

Supervised classification of respective years were showed in Figure 6. Spatial changes of forest cover was hard to detect precisely due to the low resolution of source satellite images. Although some places were identified as destructed areas. Karadikkuli, Mullikkkulam, Periyamurripu, Vilattikulam, Vannankulam, Arippu, Silavaturai, Nanaddan and Murunkan areas were destructed from 2008 to 2015. 


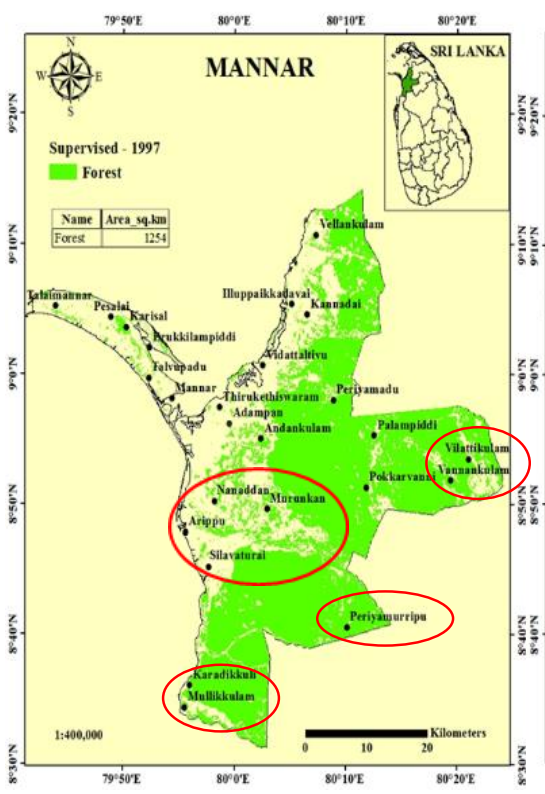

A

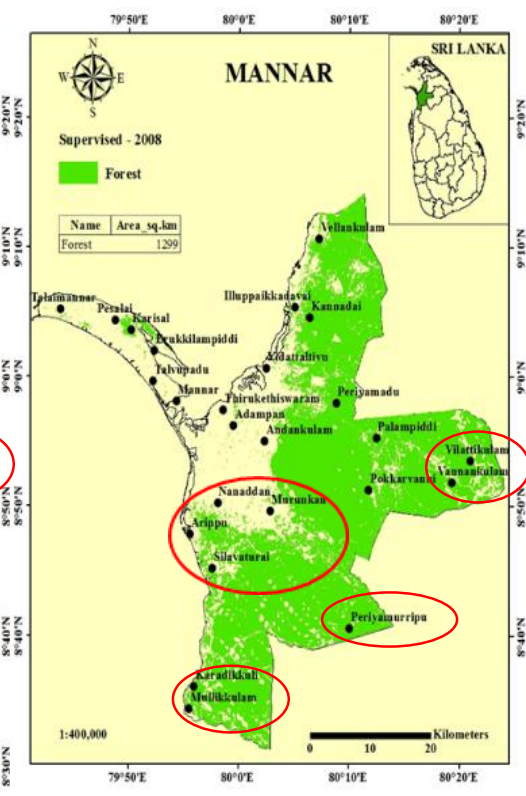

B

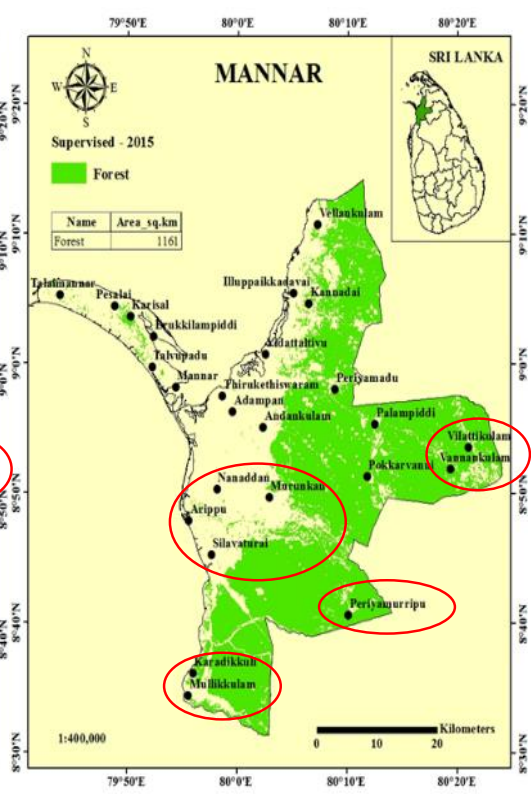

$\mathrm{C}$

Fig. 6. Satellite map of Mannar district showing Forest cover by supervised classification in years A-1997, B-2008 and C-2015

\section{CONCLUSIONS}

The results revealed that high kappa accuracy and overall accuracy were obtained for supervised classification compared to the unsupervised classification and NDVI for the years 1997, 2008 and 2015. The study indicated based on the supervised classification the forest cover extent of 1997, 2008 and 2015 were approximately $1,254 \mathrm{~km}^{2}(63 \%), 1,299 \mathrm{~km}^{2}$ $(65 \%)$ and $1,161 \mathrm{~km}^{2}(59 \%)$. It revealed that, $2 \%$ of forest cover was increased from 1997 to 2008 and 6\% was reduced from 2008 to 2015 . The study concluded that forest cover reduction is a very serious environmental problem in the district, where about 119 $\mathrm{km}^{2}(6 \%)$ of total forest cover has been reduced in 2015. Some places were identified as destructed areas. Karadikkuli, Mullikkkulam, Periyamurripu, Vilattikulam, Vannankulam, Arippu, Silavaturai, Nanaddan and Murunkan areas of forest cover were destructed. This study may be useful to manage the forest in sustainable manner and as input data for further studies by relevant stakeholders.

\section{REFERENCES}

[1] FAO, (2010). Global Forest Resources Assessment Main Report, FAO Forestry
Paper 163, Food and Agriculture Organization of the United Nations, (pp- 340. 978-92-5-106654-6.)

[2] Geist, H.J. and Lambin, E.F. (2001). What Drives Tropical Deforestation, A Metaanalysis of Proximate and Underlying Causes of Deforestation Based on Subnational Case Study Evidence. LULC Report Series No 4, Louvain-la-Neuve, Belgium, University of Louvain.

[3] Giri, C., Defourny, P. and Shrestha, S. (2003). Land cover characterization and mapping of continental Southeast Asia using multi-resolution satellite sensor data. International Journal of Remote Sensing 24(21), (pp. 4181-4196).

[4] Grigorescu, I., Mitrica B., Kucsicsa, G.H., Popovici, A., Dumitraşcu, M. and Cuculici, R. (2012). Post-communist land use changes related to urban sprawl in the Romanian Metropolitan Areas, Human Geographies. Journal of Studies and Research in Human Geography, 6(1), (pp. 35-46).

[5] Jagath Ratnayake, Mahinda Abeykoon and Yann Chemin. (Undated) District wise forest area variation in Sri Lanka from 1992 to 2001 for supporting the National Physical Planning Policy, Information and Scientific Research Unit, National Physical Planning Department 
Ministry of Western Region Development, Government of Sri Lanka.

[6] Silva, P. (2001). Land Use Changes in Sri Lanka. Report number 03. Background information for preparation of National Physical Planning Policy. Center for National Physical Planning, Urban Development Authority, National Physical Planning Department, Government of Sri Lanka.

[7] Conservator of Forests. (1996). Administration report. Ministry of Forest and Environment, Forest Department, Government of Sri Lanka.

[8] Kumar, D., Borah, S. and Shankar, U. (2010). Monitoring forest cover change using remote sensing in Amchang Wildlife Sanctuary, Assam, India. Communicated Data.

[9] Mannar distrit northern province of Sri Lanka, (2011). [Online] Available at: http://www.isea.lk/dist.php?prov=1\&dist=3. Accessed: 20.10.2014

[10] Petta, R.A., Carvalho, L.V., Erasmi, S. and Jones, C. (2013). Evaluation of desertification processes in serido region (NE Brazil). International Journal of Geoscience.4, (pp. 12-17).

[11] Temesgen, G., Amare, B. and Abraham, M. (2014). Evaluations of Land Use/Land Cover Changes and Land Degradation in Dera District, Ethiopia: GIS and Remote Sensing Based Analysis. Int. J. Sci. Res.Environ. Sci. 2(6), (pp. 199-208).

[12]Esri (3). (2014). Iso Cluster Unsupervised Classification, 10.3.

http://desktop.arcgis.com/:http://desktop.arc gis.com/en/arcmap/10.3/tools/spatialanalyst-toolbox/iso-cluster-unsupervisedclassification.htm

[13] Churches, C.E., Wampler, P.J., Sun, W. and Smith, A.J. (2014). Evaluation of forest cover estimates for Haiti using supervised classification of Landsat data. International Journal of Applied Earth Observation Geoinformatics 30, (pp. 203-216).

[14] Ghebrezgabher, M. G., Taibao Yang., Xuemei Yang., Xin Wang. and Masihulla Khan. (2016). Extracting and analyzing forest and woodland cover change in Eritrea based on landsat data using supervised classification. The Egyptian Journal of Remote Sensing and Space Sciences. 19, (pp. 37-47). 